PNL-7264

UC-600

\title{
Archaeological Survey of the 200 East and 200 West Areas, Hanford Site, Washington
}

J. C. Chatters

N. A. Cadoret

March 1990

Prepared for the U.S. Department of Energy under Contract DE-AC06-76RLO 1830

Pacific Northwest Laboratory Operated for the U.S. Department of Energy by Battelle Memorial Institute 


\title{
DISCLAIMER
}

This report was prepared as an account of work sponsored by an agency of the United States Government. Neither the United States Government nor any agency thereof, nor Battelle Memorial Institute, nor any of their employees, makes any warranty, expressed or implied, or assumes any legal liabdity or responsibility for the accuracy, completeness, or usefulness of any information, apparatus, product, or process disclosed, or represents that its use would not intringe privately owned rights. Reference herein to any specific commercial product, process, or service by trade name, trademark, manufacturer, or otherwise, does not necessarily constitute or imply its endorsement, recommendation, or favoring by the United States Government of any agency thereof, or Battelle Memorial Institute. The views and opinions of authors expressed herein do not necessarily state or reflect those of the United States Government or any agency thereof.

\author{
PACIFIC NORTHWEST LABORATORY \\ operated by \\ BATTELLE MEMORIAL INSTITUTE \\ for the \\ UNITED STATES DEPARTMENT OF ENERGY \\ under Contract DE-ACO6-76RLO 1830
}

Printed in the United States of America

Avaitable to DOE and DOE contractors from the

Office of Scientific and Technical Information, P.O. Box 62, Oak Ridge, TN 37831; prices available from (615) 576-8401. FTS 626-8401.

Available to the public from the National Technical Information Service,

U.S. Department of Commerce, 5285 Port Royał Rd., Springfield, VA 22161.

NTIS Price Codes, Microfiche A01

Printed Copy

\begin{tabular}{cr}
\hline Prke Code & Page Range \\
\hline A02 & $1-10$ \\
A03 & $11-50$ \\
A04 & $51-75$ \\
A05 & $76-100$ \\
A06 & $101-125$ \\
A07 & $126-150$ \\
A08 & $151-175$ \\
A09 & $176-200$ \\
A10 & $201-225$ \\
A11 & $226-250$ \\
A12 & $251-275$ \\
A13 & $276-300$ \\
A14 & $301-325$
\end{tabular}

\begin{tabular}{cc}
\hline Price Code & Page Range \\
\hline A15 & $326-350$ \\
A16 & $351-375$ \\
A17 & $376-400$ \\
A18 & $401-425$ \\
A19 & $426-450$ \\
A20 & $451-475$ \\
A21 & $476-500$ \\
A22 & $501-525$ \\
A23 & $526-550$ \\
A24 & $551-575$ \\
A25 & $576-600$ \\
A99 & $601-U p$
\end{tabular}


ARCHAEOLOGICAL SURVEY OF THE 200 EAST AND 200 WEST AREAS, HANFORD SITE, WASHINGTON

\author{
J. C. Chatters \\ N. A. Cadoret
}

March 1990

Prepared for the U.S. Department of Energy under Contract DE-AC06-76-RLO 1830

Pacific Northwest Laboratory

Richland, Washington 99352 



\section{EXECUTIVE SUMMARY}

Responding to a heavy demand for cultural resource reviews of excavation sites, the Westinghouse Hanford Company contracted with Pacific Northwest Laboratory(a) to conduct a comprehensive archaeological resource review for the 200 Areas of the Hanford Site, Washington. This was accomplished through literature and records review and an intensive pedestrian survey of all undisturbed portions of the 200 East Area and a stratified random sample of the 200 West Area.

The survey, conducted by the Hanford Culural Resources Laboratory in August and September 1988 followed the Secretary of the Interior's guidelines for the identification of historic properties. The result of the survey is a model of cultural resource distributions that has been used to create cultural resource zones with differing degrees of sensitivity. The outcome is that no further archaeological surveys will be needed in the 200 East Area and will be required in the 200 West Area only within $100 \mathrm{~m}$ of the historic White Bluffs Road. Facilities demolition and renovation are not covered by this clearance and will continue to require cultural resource reviews.

(a) Pacific Northwest Laboratory is operated for the U.S. Department of Energy by Battelle Memorial Institute. 


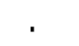

,

.

. 


\section{CONTENTS}

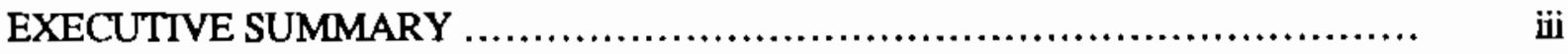

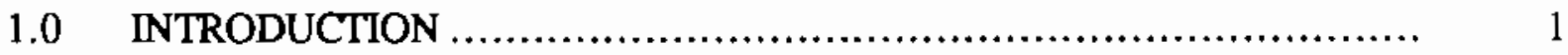

2.0 DESCRIPTION OF THE 200 AREAS ...................................... 3

$3.0 \quad$ RESEARCH DESIGN ............................................... 9

3.1 PREVIOUS ARCHAEOLOGICAL RESEARCH IN THE

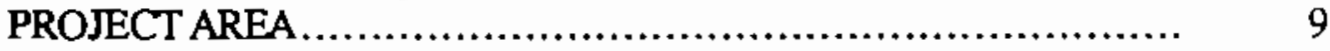

$3.2 \quad$ INTENSIVE SURVEY ........................................... 10

4.0 CULTURAL RESOURCES OBSERVED ................................. 11

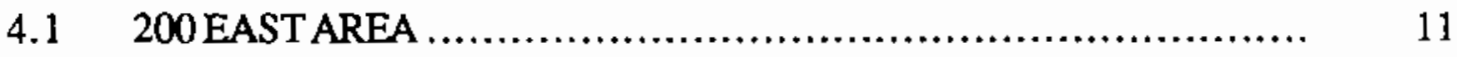

$4.2 \quad 200$ WEST AREA .................................................. 11

5.0 EVALUATION OF CULTURAL RESOURCE SITES........................ 17

5.1 EVALUATTON OF HT-88-001 AND HT-88-009.................... 17

5.2 EVALUATION OF THE WHITE BLUFFS ROAD ................... 17

6.0 CONCLUSIONS AND RECOMMENDATIONS .......................... 21

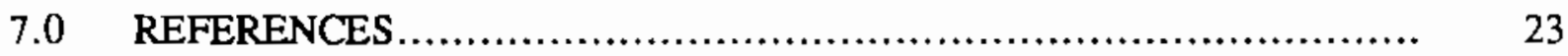




\section{EIGURES}

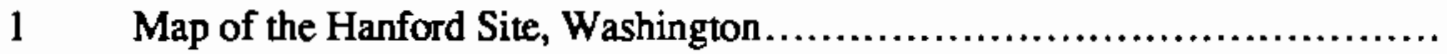

2 Map of the 200 West Area Showing Areas Previously Surveyed, Areas Surveyed for the PCB/Pu Storage

Facility, the Hanford Central Waste Complex, and Survey

Plots Defined for the Comprehensive Review, $\mathrm{T} 12$ and

$13 \mathrm{~N}, \mathrm{R} 25$ and $26 \mathrm{E}$, USGS Riverland and Gable Butte $7.5^{\prime}$

Quadrangles, 1986 Provisional Editions .........................................

3 Map of the 200 East Area Showing Areas Previously Surveyed, Area Surveyed for the Regulated Maintenance Equipment Facility, and Plots Surveyed for the Comprehensive Review, T 12 and 13 N, R 26 E, USGS Gable Butte 7.5' Quadrangle, 1986 Provisional Edition .............................. 6

4 Location of Isolated Artifacts Within the 200 East Area...................... 12

5 Location of Sites and Isolated Artifacts Within and in the Vicinity of the 200 West Area ........................................... 13

6 Aerial View of the White Bluffs Road ..................................... 14

7 View of the White Bluffs Road from the 200 West Area...................... 14

\section{TABLE}

1 Archaeological Surveys Conducted by Hanford Cultural

Resources Laboratory in the 200 East and 200 West Areas..................... 


\subsection{INTRODUCTION}

It is currently the policy of the Richland Operations Office of the U. S. Department of Energy (DOE-RL) to conduct cultural resource reviews of all projects and activities that entail ground disturbance on the Hanford Site. Programs in the 200 Areas (Figure 1), which are the scene of nuclear materials processing and waste management, have been the heaviest consumers of cultural resource review services. During the second half of fiscal year (FY) 1987, the first period of intensive cultural resource regulatory compliance, the 200 Areas accounted for $35 \%$ of the 40 reviews conducted. During the first 10 months of FY $1988,42 \%$ of 169 reviews had been in that area of the Hanford Site. With the growing waste management role of the 200 Areas, this high demand for cultural resource reviews was expected to continue. Because this approach to cultural resource compliance is not cost effective, DOE-RL decided, in consultation with the Washington State Historic Preservation Officer, to conduct a comprehensive archaeological review of fenced portions of the 200 Areas.

This report reviews previous archaeological research in the 200 Areas and similar environments, describes the strategy and tactics of the archaeological review, discusses results of that review, and provides recommendations for the cultural resource zoning of the 200 Areas. In addition to surveys conducted specifically for archaeological clearance, this report incorporates Section 106 reviews for the PCB/Pu Storage Facility (HCRC \#87-200-021), the Hanford Central Waste Complex (HCRC \#88-200-005), and the Regulated Equipment Maintenance Facility (HCRC \#88-200-034). (a)

(a) Projects planned and facilitated by the Facilities Projects Group, Site Planning, and Tank Farm Projects of Westinghouse Hanford Company, Richland, Washington. 


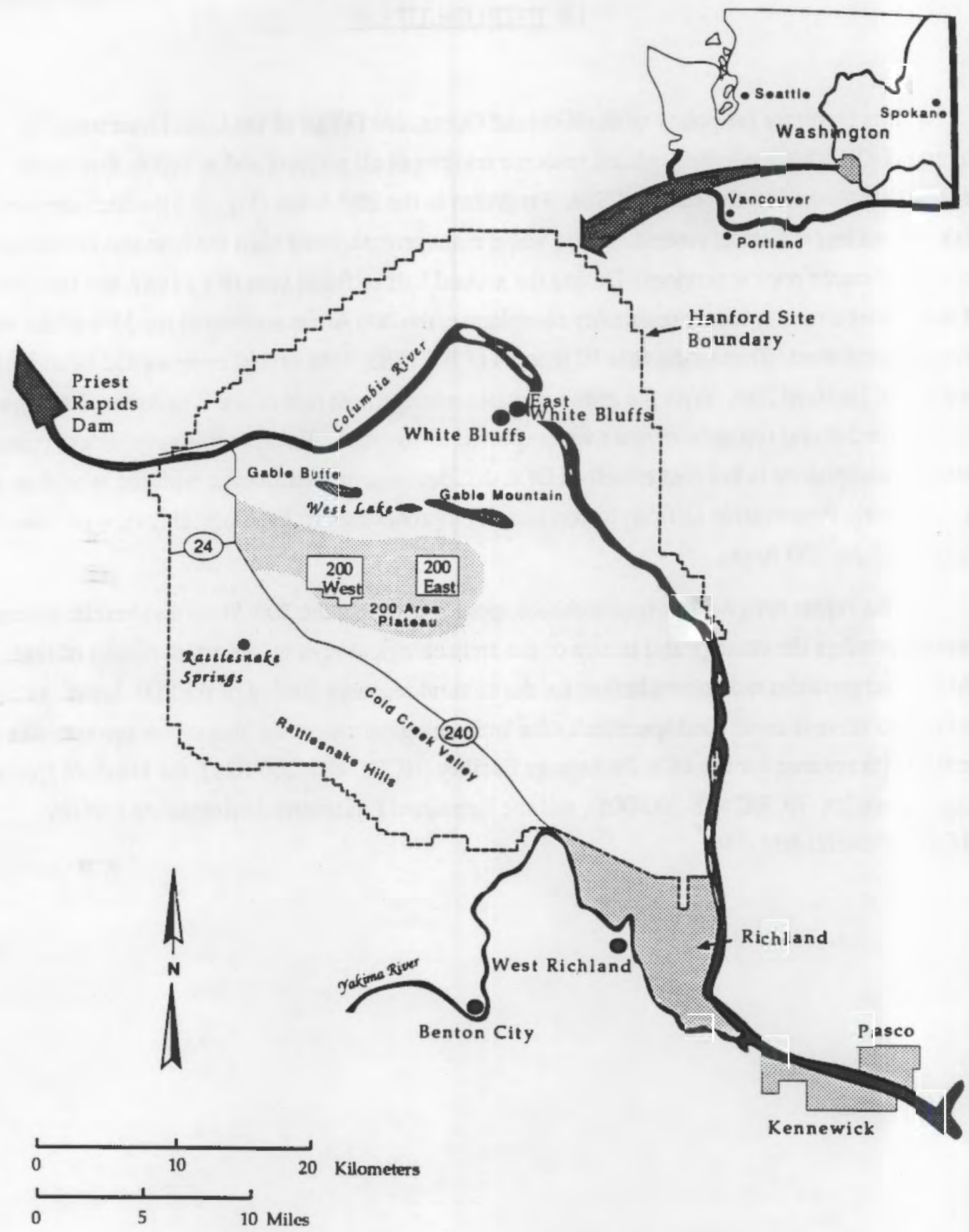

FIGURE 1. Map of the Hanford Site, Washington 


\subsection{DESCRIPTION OF THE 200 AREAS}

The 200 Areas are located near the center of the Hanford Site in Benton County, Washington, approximately $11 \mathrm{~km}$ and $8 \mathrm{~km}$, respectively, south of the Columbia River (see

Figure 1). Established in 1943, these areas are dedicated to fuel processing and waste disposal activities. The fuel processing, plutonium separation, and plutonium finishing portions of operations on the Hanford Site are located here. Additional activities in these areas include plutonium scrap processing; waste fractionization; laboratory work; and management of high-level, low-level, transuranic, and tank radioactive wastes resulting from the separation process.

Combined, the 200 East and 200 West Areas occupy approximately $15.5 \mathrm{~km}^{2}$, most of it on a broad, rolling, upland flat commonly referred to as the 200 Area Plateau. The southwest part of the 200 West Area is within the Cold Creek Valley, a lower-lying basin that lies between the 200 Area Plateau and Rattlesnake Ridge. The transition between the 200 Area Plateau and the Cold Creek Valley is marked by a slope approximately $36 \mathrm{~m}$ high with a gradient between $2 \%$ and $11 \%$. Small-scale hummocks, known as coppice dunes, with amplitudes of 0.2 to $0.3 \mathrm{~m}$ are associated with vegetarion. The area is dry, with the nearest perennial water sources being West Lake (marked as a spring on the 1916 U.S. Geological Survey 15' Coyote Rapids Quadrangle Map), located $3.3 \mathrm{~km}$ north of the 200 East Area, and Rattlesnake Springs, located $5.4 \mathrm{~km}$ southwest of the 200 West Area.

The areas are generally uniform lithologically and ecologically. Surface sediments are composed of eolian silty sand overlying glaciofluvial sand and gravel. Mt. St. Helens' tephra from the 1980 eruption forms a thin, discontinuous layer at or near the surface.

The vegetation is a shrub-steppe community (Daubenmire 1970) dominated by big sagebrush (Artemisia tridentata) with an understory of grasses and forbes. Grasses present included cheatgrass (Bromus tectorum), Sandberg's bluegrass (Poa sandbergii), Indian ricegrass (Oryzopsis hymenoides), bottlebrush squirreltail (Sitanion hystrix), and wheatgrass (Agropyron sp). Forbs present included Carey's balsamroot (Balsamorhiza careyana), yarrow (Achillea millefolium), turpentine cymopterus (Cymopterus terebinthinus), ragweed, (Ambrosia sp.), toad flax (Comandra umbellata), tumblemustard (Sisymbrium altissimum), salsify (Tragopogon dubius), phlox (Phlox longifolia), milk vetch (Astragalus sp.), aster (Machaeranthera canescens), cryptantha (Cryptantha spp.), globe mallow (Shaeralcea munroana), skeletonweed (Lygodesmia iuncea), and fiddleneck (Amsinckia sp). Tumbleweed (Salsola kaii) is common in disturbed areas. Other shrubs noted included gray rabbitbrush (Chrysothamnus nauseosus), green rabbitbrush 
(Chrysothamnus visidiflorus), occasional bitterbrush (Pershia tridentata) in the 200 East Area, and occasional spiny hopsage (Atriplex spinosa) in that portion of the 200 West Area that is located in Cold Creek Valley. The average ground cover was approximately $30 \%$ to $40 \%$ at the time the surveys were conducted.

The PCB/Pu Storage Facility and the proposed Hanford Central Waste Complex are located in the northeast corner of the 200 West Area (Figure 2). The PCB/Pu Storage Facility was installed for the storage of polychlorinated biphenyl (PCB) oil contaminated with plutonium-239 $\left({ }^{239} \mathrm{Pu}\right)$. The prefabricated facility measures $371 \mathrm{~m}^{2}(15.2 \mathrm{~m}$ by $24.4 \mathrm{~m})$. The Hanford Central Waste Complex will include a number of storage facilities and a solid waste processing building. The complex will occupy $0.4 \mathrm{~km}^{2}$, including that area designated for the PCB/Pu Storage Facility. The Regulated Equipment Maintenance Facility will impact a 2-acre area in the 200 East Area (Figure 3). 

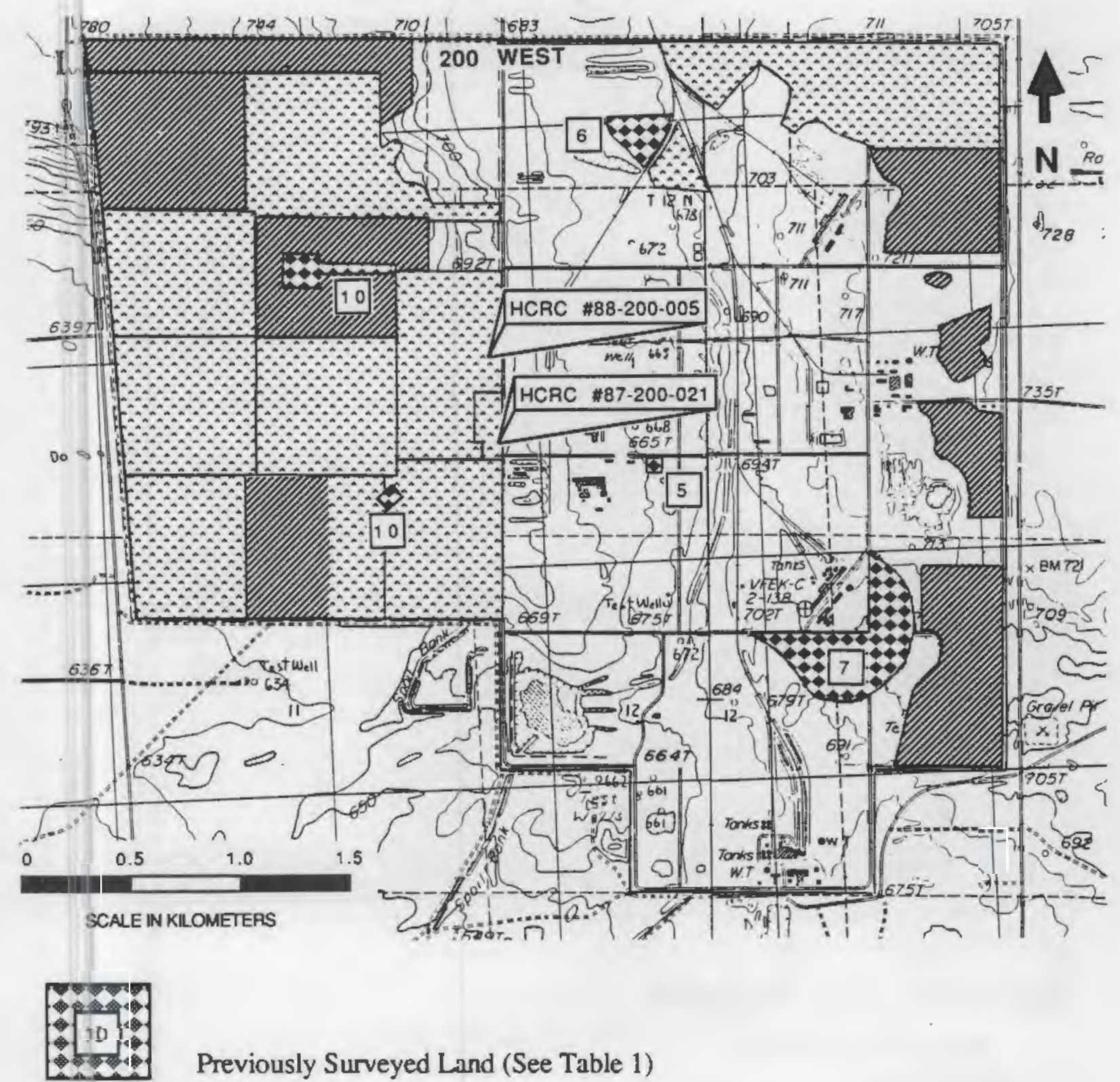

Previously Surveyed Land (See Table 1)

Project-Driven Surveys and Plots Surveyed for the Comprehensive Review

Plots Defined for the Comprehensive Review but Not Surveyed

FIGURE 2. Map of the 200 West Area Showing Areas Previously Surveyed, Areas Surveyed for the PCB/Pu Storage Facility (HCRC \#87-200-021), the Hanford Central Waste Complex (HCRC \#88-200-005), and Survey Plots Defined for the Comprehensive Review, T 12 and $13 \mathrm{~N}, \mathrm{R} 25$ and $26 \mathrm{E}$, USGS Riverland and Gable Butte 7.5' Quadrangles, 1986 Provisional Editions. 

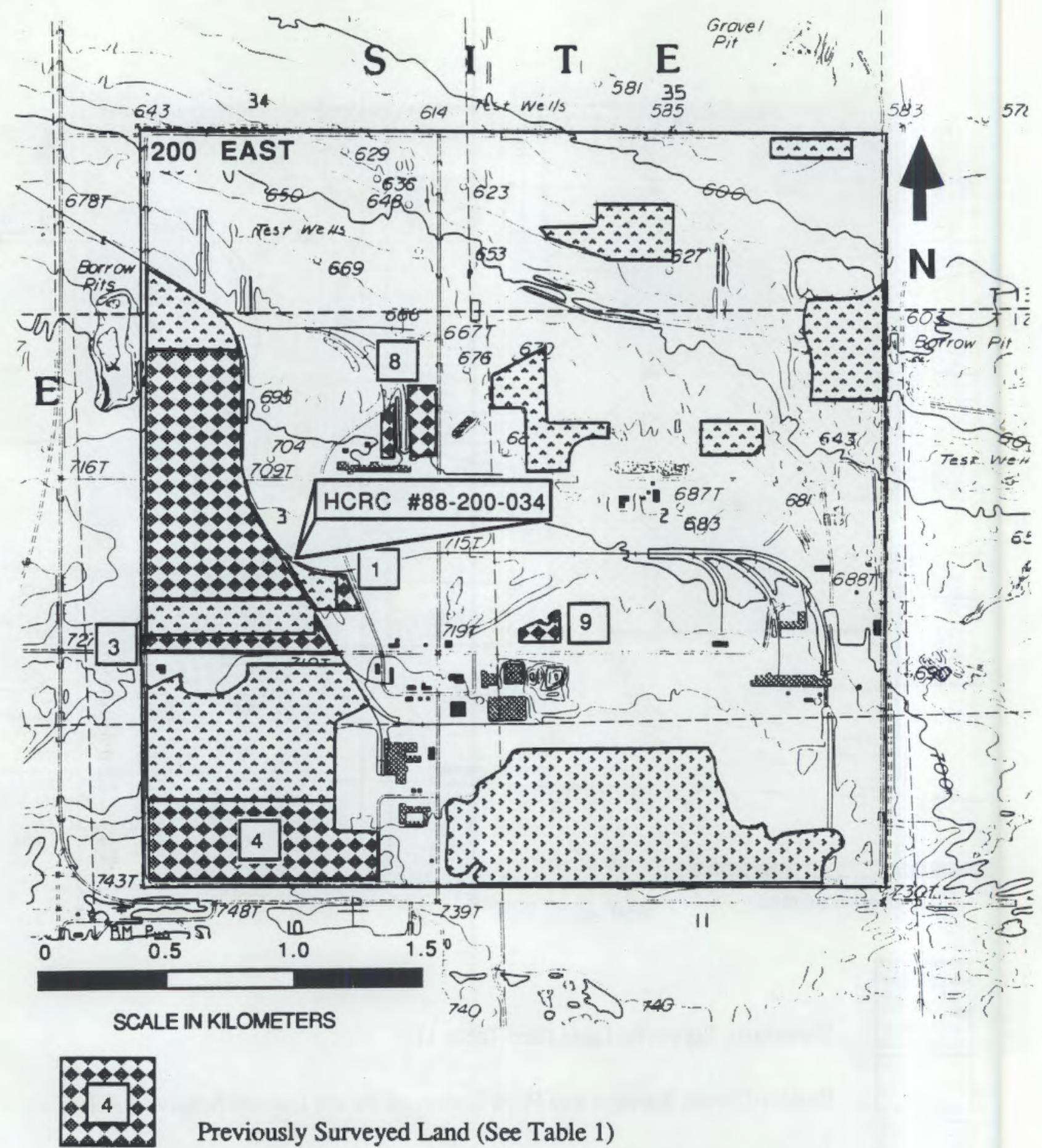

Previously Surveyed Land (See Table 1)

烈

Project-Driven Survey and Plots Surveyed for the Comprehensive Review

FIGURE 3. Map of the 200 East Area Showing Areas Previously Surveyed, Area Surveyed for the Regulated Maintenance Equipment Facility (HCRC \#88-200-034), and Plots Surveyed for the Comprehensive Review, T 12 and 13 N, R 26 E, USGS Gable Butte 7.5' Quadrangle, 1986 Provisional Edition. 
TABLE 1. Archaeological Surveys Conducted by Hanford Cultural Resources Laboratory in the 200 East and 200 West Areas

\section{Map Reference} Number

1

HCRC \#87-200-014
HCRC \#87-200-005, HCRC \#87-200-008

Project Number

HCRC \#87-200-003

HCRC \#87-200-004

HCRC \#87-200-012

\section{Reference}

Chatters, J. C. 1987. Cultural Resources Survey of the Proposed Rigging Services Facility, Hanford Site, Washington, HCRC \#87-200-003. Letter report submitted to the U.S. Department of Energy, Richland Operations, Richland, Washington.

Chatters, J. C. 1987. Cultural Resources Survey of the Proposed Hanford Waste Vitrification Plant, HCRC \#87-200-004. Letter report submitted to the U.S. Department of Energy, Richland Operations, Richland, Washington.

Chatters, J. C. and N. A. Cadoret 1988a. Cultural Resources Survey of the proposed Steam System Rehabilitation, Phase I, HCRC \#87-200-005, and the Proposed Water System Upgrades-Reservoir, HCRC \#87-200-008. Letter report submitted to the U.S. Department of Energy, Richland Operations, Richland, Washington.

Chatters, J. C. and N. A. Cadoret 1988b. Cultural Resources Survey of the Proposed 200-East Unsecured Core Area Facilities Project, HCRC \#87-200-012. Letter report submitted to the U.S. Department of Energy, Richland Operations, Richland, Washington.

Chatters, J. C. and N. A. Cadoret 1987. Cultural Resources Survey of the Proposed 200-West Plutonium Finishing Plant Parking Lot Improvements, HCRC \#87-200-014. Letter report submitted to the U.S. Deparıment of Energy, Richland Operations, Richland, Washington.

Cadoret, N. A. and J. C. Chatters 1988a. Cultural Resources Survey of the Proposed 200-West 218-W-3A, 218-W-3AE, and 218-W-5 Waste Trenches, HCRC \#87-200-016. Letter report submitted to the U.S. Department of Energy, Richland Operations, Richland, Washington. 


\section{TABLE 1. (contd)}

Map Reference Number

8
Project Number

HCRC \#88-200-032

HCRC \#88-200-037

HCRC \#88-200-046

BWIP Boreholes
Reference

\section{Letter from N. A. Cadoret to C. E. Hodge 1/14/88}

Hoover, K. A. and J. C. Chatters 1988. Cultural Resources Survey of the 200-East Area B-Plant Facilities, HCRC \#87-200-037. Letter report submitted to the U.S. Department of Energy, Richland Operations, Richland, Washington.

Chatters, J. C. 1988. Cultural Resources Survey of the Proposed B-503 Decontamination Laundry Facility, HCRC \#87-200-046. Letter report submitted to the U.S. Department of Energy, Richland Operations, Richland, Washington.

Staff of the HCRL, March 1988. BWIP Archaeological and Cultural Resources Field Studies. Letter report submitted to the U.S. Department of Energy, Richland Operations, Richland, Washington. 


\subsection{RESEARCH DESIGN}

The archaeological survey of the 200 Areas was conducted in two phases: a literature review and an intensive pedestrian survey. The document reviews consisted of referring to the Hanford Cultural Resources Laboratory (HCRL) cultural resources site and aerial photograph files and reading relevant portions of pertinent archaeological reports. The intensive survey consisted of inspecting project locations plus a sample of lands not yet scheduled for development. Findings of the literature review (Section 3.1) and details of the intensive survey procedure (Section 3.2) are described in this section.

\subsection{PREVIOUS ARCHAEOLOGICAL RESEARCH IN THE PROJECT AREA}

Archaeological surveys conducted in the Pasco Basin have often sampled environmental settings similar to those of the 200 Areas. In particular, Rice $(1980,1984)$, Smith and others (1977), ERTEC (1982), and the HCRL all sampled nonriverine settings of the Hanford Site, and Chatters (1980) inspected numerous plots north and east of the Site. Most recently, Pacific Northwest Laboratory (PNL) conducted a survey of a stratified random sample of Hanford Site as part of the Basalt Waste Isolation Project (BWIP) to ascertain the characteristics and distribution of archaeological resources. All these surveys found artifacts concentrated in areas of high topographic relief or with nearby sources of permanent water. There was almost no evidence of aboriginal activity in open inland flats. Exceptions occurred near historically recorded Indian trails and consisted of isolated projectile points and flake tools. The distribution of historic trash was largely random with respect to environmental features, except that it too was concentrated near the White Bluffs Road.

Surveys conducted inside the 200 Areas have had similar results. For example, Rice (1984) conducted a reconnaissance of nearly $49 \mathrm{~km}^{2}$ on the 200 Area Plateau and Cold Creek Valley, including a section of the 200 West Area (see Figure 2). He recorded no archaeological sites or isolated artifacts within the 200 West Area, although he did note a scatter of eight flakes of cryptocrystalline stone along the White Bluffs Road, southwest of the 200 West Area. He also noted occasional fragments of crockery and bottle glass along the road bed (exact locations not given). Ten smaller-scale archaeological surveys have been conducted by HCRL within the 200 East and 200 West Areas (Table 1, Figures 2 and 3) and resulted in the discovery of only one artifact: a side-soldered can found along the White Bluffs Road. 


\subsection{INTENSIVE SURVEY}

The surveys reported here were conducted for two purposes: to inspect project sites for cultural resources and to develop archaeological sensitivity zones within the 200 Areas. Although survey techniques followed standard HCRL procedures (Chatters 1989), the manner of choosing land to be surveyed differed for the two purposes.

The areas covered by project-driven surveys were determined by the boundaries of the proposed projects. All areas that had not previously been leveled and filled were inspected.

The survey conducted to develop archaeological sensitivity zonation also focused on undisturbed land, which was identified from aerial photographs before fieldwork began. In the 200 East Area, where only a small portion of the land surface remained undisturbed, all undisturbed, previously unsurveyed surfaces were inspected. A much larger portion of the 200 West Area was in a natural state, necessitating a sampling design. In all, a $5.05-\mathrm{km}^{2}$ area was surveyed under the project-driven and comprehensive reviews, $1.46 \mathrm{~km}^{2}$ of the area in the 200 East Area and $3.59 \mathrm{~km}^{2}$ in the 200 West Area.

A $50 \%$ sample of undisturbed, previously unsurveyed 200 West Area land was chosen using a stratified random sampling design. Sampling strata were taken from the Hanford Site-wide environmental zone scheme developed for the sample cultural resource inventory of the Site as a whole (Chatters 1989), and included inland, flat environmental zones and a small portion of the escarpment zone. Each zone was divided into numbered parcels of approximately equal size (although shapes were highly variable), and a $50 \%$ sample was chosen for survey.

Intensive pedestrian surveys were conducted on November 6, 1987, for the PCB/Pu Storage Facility; on February 3 and 5, 1988, for the Hanford Central Waste Complex; on August 2, 1988, for the Regulated Equipment Maintenance Facility; and between August 12 and September 8, 1988, for the 200 Area comprehensive review. Surveys were conducted by PNL staff members R. W. Beinert, N. A. Cadoret, J. C. Chatters, M. K. Jackson, N. V. Marr, and W. H. Rickard. 


\subsection{CULTURAL RESOURCES OBSERVED}

This section describes the cultural resources, including isolated artifacts, sites, and cultural features that were found during the above-described surveys in the 200 East and 200 West Areas.

\subsection{EAST AREA}

The only artifacts more than 50 years old that were found in the 200 East Area were two isolated historic artifacts: a hole-in-top can (HI-88-024), and a flat-topped crimped can (HI-88-025), (Figure 4). Other cultural materials observed included two fan-shaped trellises and screens, age and function of which are not known.

\subsection{WEST AREA}

Altogether, one extensive cultural feature (White Bluffs Road), two historic archaeological sites, and three isolated artifacts (two of historic manufacture and one attributable to Native American use) were recorded during survey of the 200 West Area (Figure 5).

\subsubsection{The White Bluffs Road}

A segment of the historic White Bluffs Road is located within the 200 West Area. The road trends northeast by northwest across the area (see Figure 5). In the southwest part of the area, the unimproved dirt road is still in use. In the central section of the area, the road has been destroyed by waste/industrial operations. In the northeast section of 200 West, approximately $0.5 \mathrm{~km}$ of the road is intact and not currently in use. It is $\sim 5$ to $6 \mathrm{~m}$ wide and $\sim 0.5$ to $1.10 \mathrm{~m}$ below grade. Vegetation growing in the roadway is similar to that growing outside of the roadway. According to Government Land Office maps of the area drawn between 1867 and 1881, the road ran diagonally from Rattlesnake Springs, northwest to White Bluffs Landing on the Columbia River. To the south and west of Rattlesnake Springs, the road zig-zagged through the hills to the Yakima River at a point near Sunnyside, Washington, where it connected with routes to The Dalles, Oregon. On the north side of the Columbia River, the road continued north to Fort Colville and British Columbia. Segments of the original roadbed can be traced on aerial photographs from Rattlesnake Springs to just southwest of the White Bluffs townsite, passing through what is now the 200 West Area (Figure 5; see also Rice 1984, Figures 5, 6, and 7). Approximately $12.5 \mathrm{~km}$ of the original $25.6 \mathrm{~km}$ of the road are intact and little altered (Figure 6). Approximately $5.9 \mathrm{~km}$ 


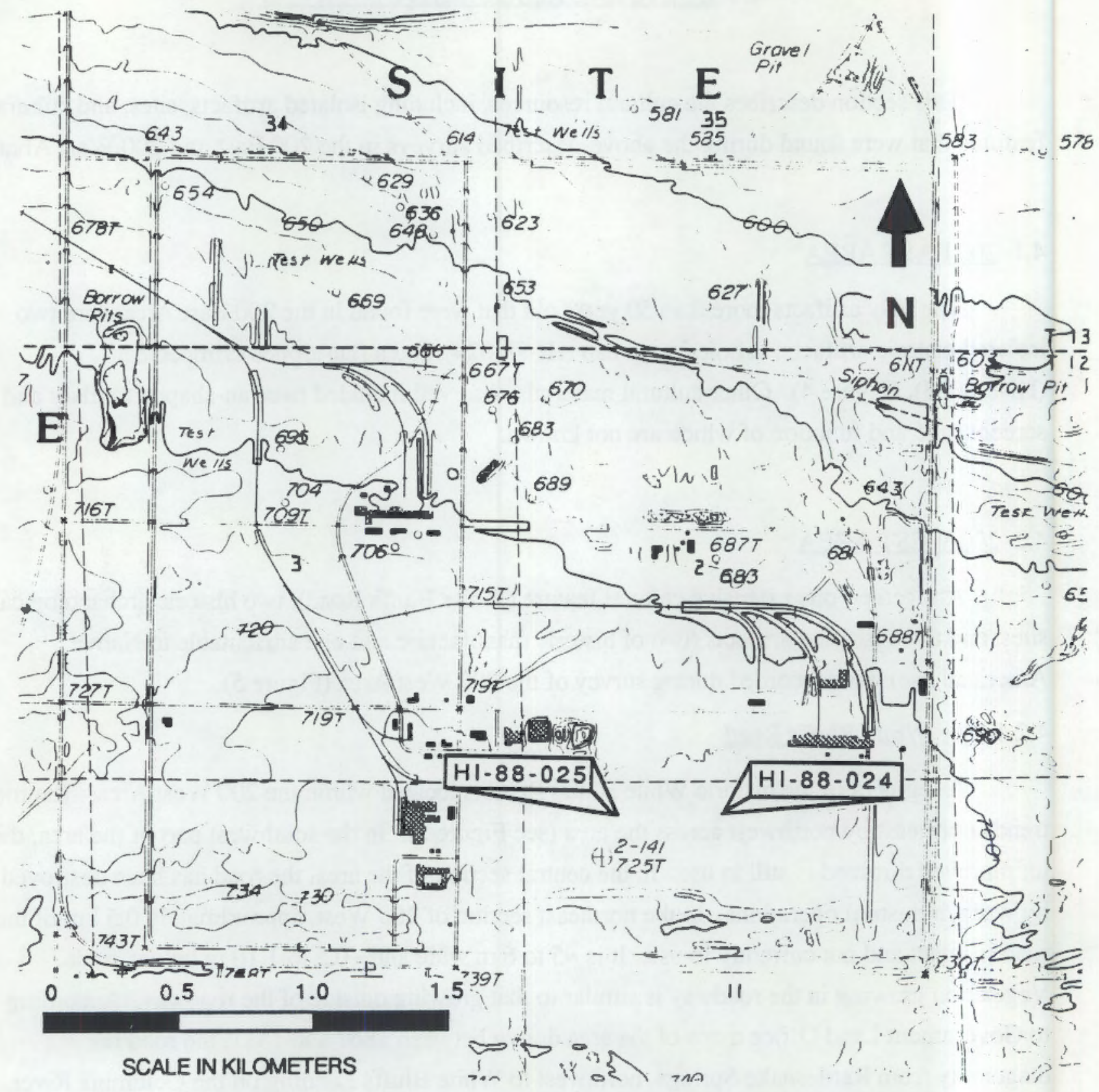

FIGURE 4. Location of Isolated Artifacts Within the 200 East Area

of the road have been destroyed by later developments, such as the growth of the town of White Bluffs, plowing of farm fields, construction of roads, railroads and utility lines, and construction of defense and waste-related facilities on the Hanford Site. Approximately $7.2 \mathrm{~km}$ of the road, of which $1.8 \mathrm{~km}$ are paved, are currently used (see Figure 7). Approximately $1.6 \mathrm{~km}$ have been 


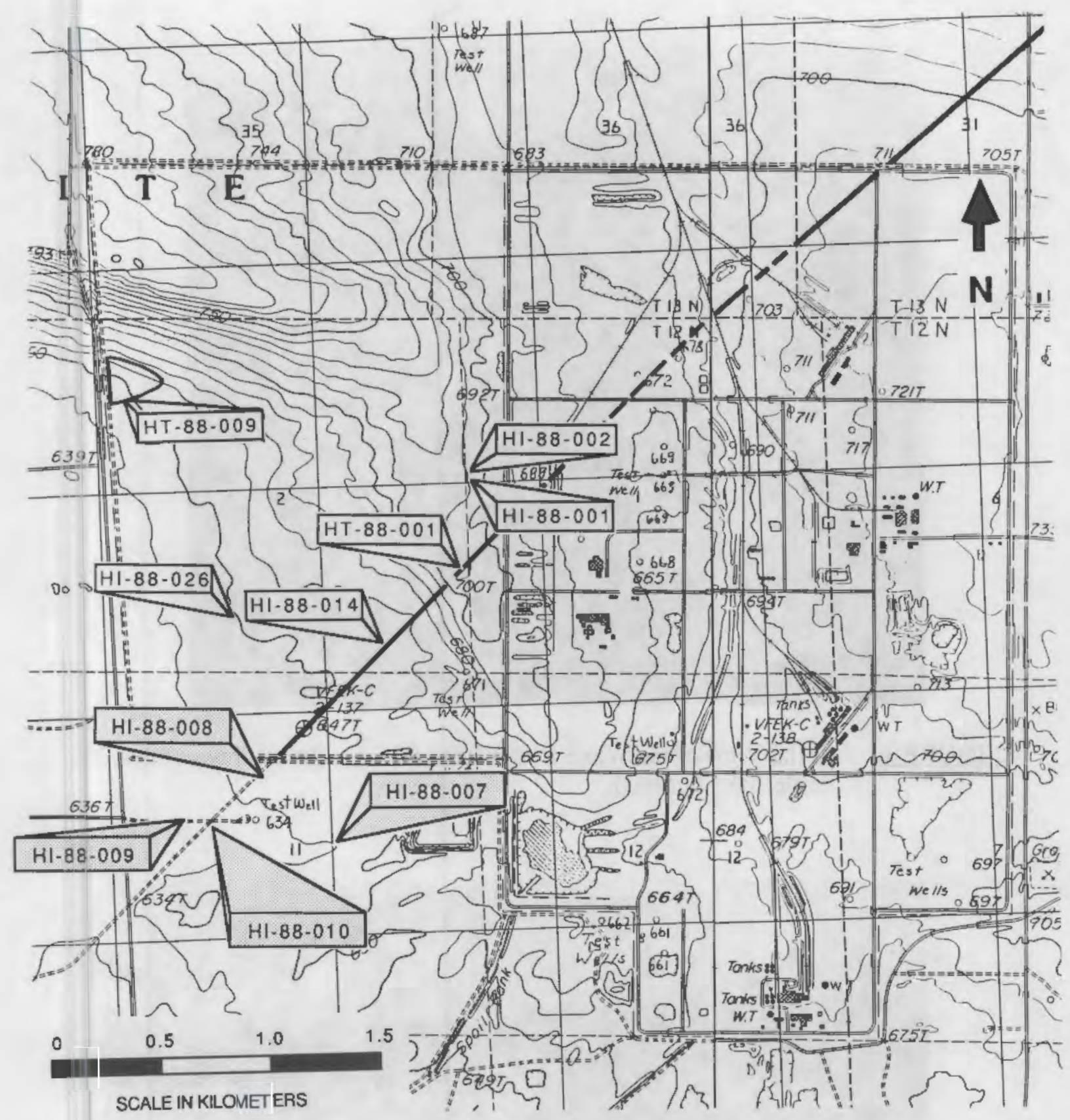

Extant Portions of the

H1-88-002 White Bluffs Road

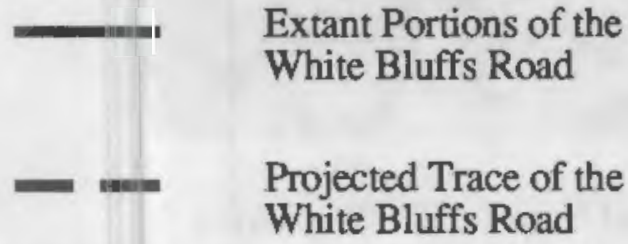

HT-88.001

Isolated Artifacts Within the 200 West Area

Sites Within the 200 West Area

Isolated Artifacts Outside of the 200 West Area

FIGURE 5. Location of Sites and Isolated Artifacts Within and in the Vicinity of the 200 West Area 


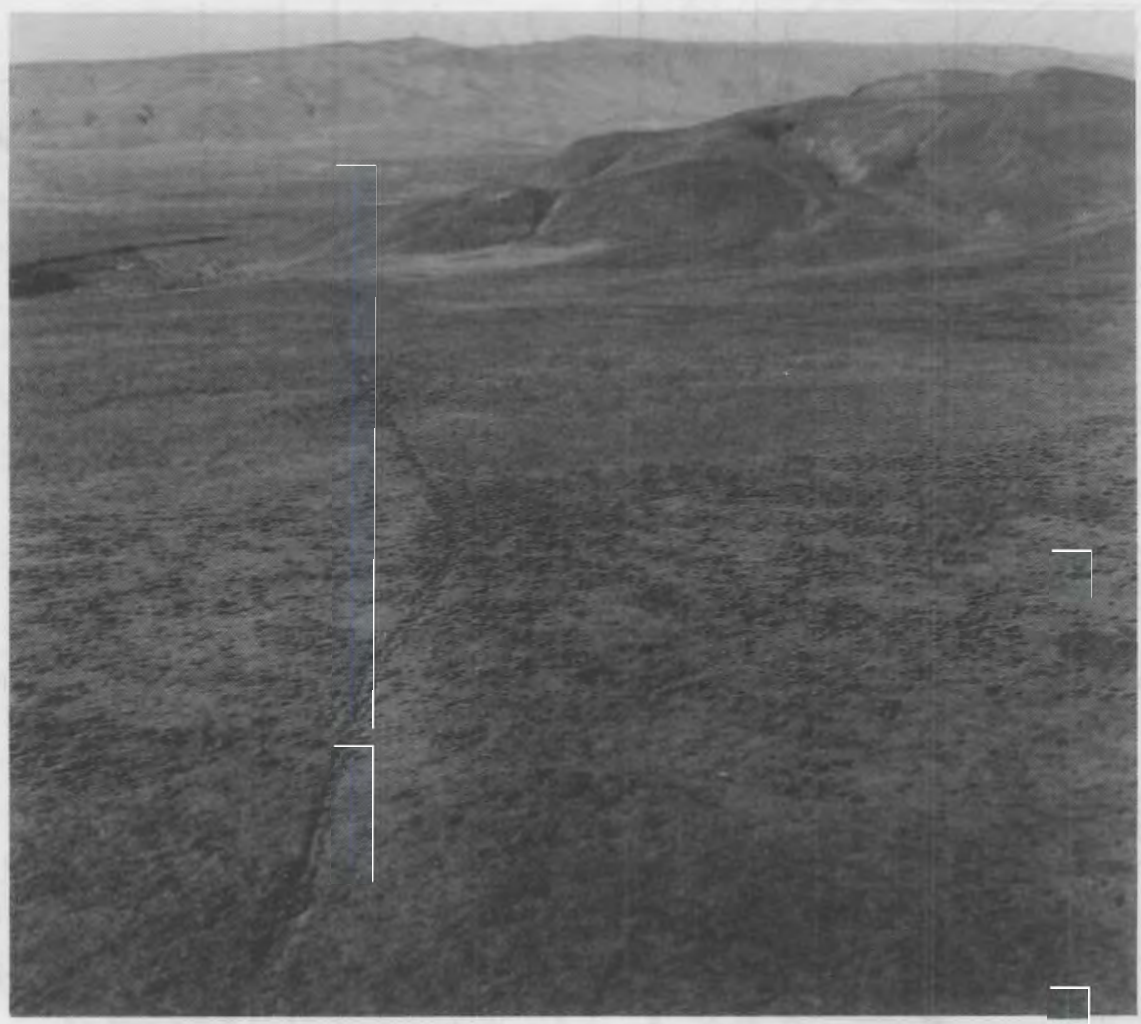

FIGURE 6. Aerial View of the White Bluffs Road (view to the southwest toward Rattlesnake Springs)

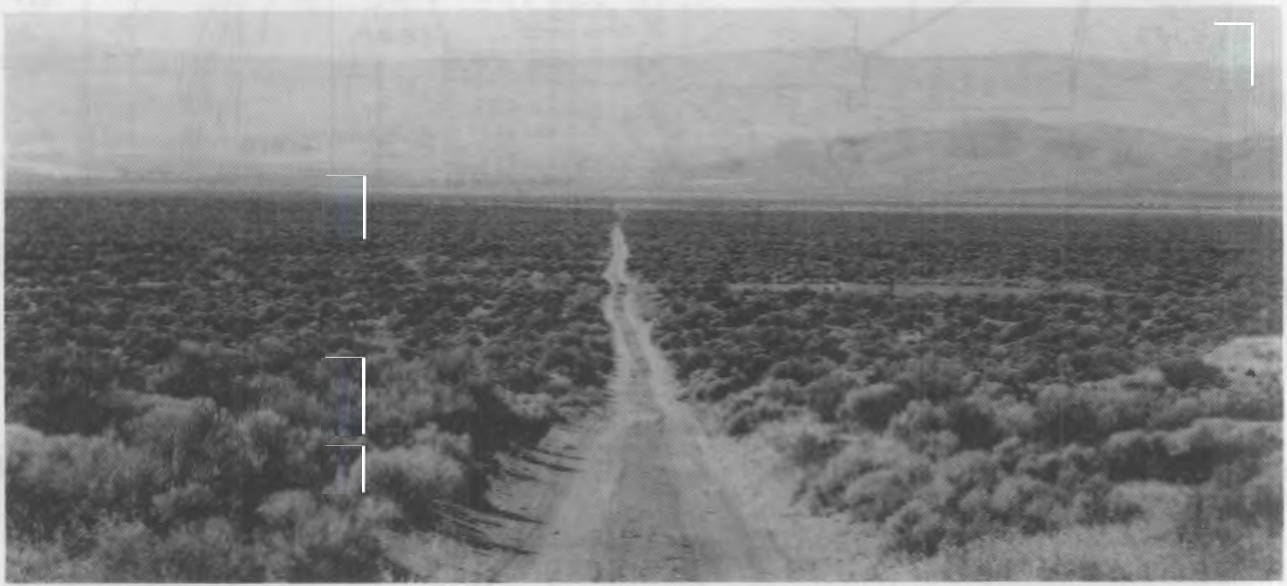

FIGURE 7. View of the White Bluffs Road from the 200 West Area (looking southwest toward Rattlesnake Springs) 
destroyed by development within the 200 West Area. The road can also be traced on the north side of the Columbia River where it is largely intact. Minor disruption has been caused by drifting sand and plowing.

Surveys conducted in 1987 by PNL as part of BWIP activities also included $1.8 \mathrm{~km}$ of the White Bluffs Road. Two cryptocrystalline flakes, HI-87-007 and HI-87-008, were found within the road. Two historical sites, a can scatter (HT-87-002), a possible homesite (HT-87-004), an isolated artifact, and an aqua bottle (HI-87-010), were also identified in proximity to the road. The sites and the isolated artifact date to the late nineteenth and early twentieth century

\subsubsection{Site HT- $88-001$}

This site, consisting of a hole-in-top can and fragments of a blue Ball jar, (a) is located on the north berm of the White Bluffs Road on the ridge crest overlooking Cold Creek Valley. The site appears to date from the late nineteenth or early twentieth century. Hole-in-top cans were first manufactured in quantity in 1811 (Berge 1980). Crimped cans were first manufactured in 1897 (University of Utah and others 1984), gradually replacing hole-in-top cans; crimped cans were generally accepted by the can industry by 1922 (Berge 1980). Ball jars were first manufactured in 1885 (Berge 1980). Kerr ${ }^{(b)}$ manufactured an indigo blue jar from 1910 to 1930, and Ball may have manufactured a similar jar at about the same time. The site probably represents a single-use stop aiong the White Bluffs Road. The location, at the crest of a hill, affords a good vantage to the southwest, and would make an attractive stopping place. None of the artifacts were collected.

\subsubsection{Site HT $-88-009$}

This site is a can and bottle scatter located near the base of the slope that separates the 200 Area Plateau from the Cold Creek Valley. Located at the site are two hole-in-top food cans, five hole-in-top evaporated milk cans, one solarized (glass turned purple by prolonged exposure to sunlight) crown-top bottle, one tobacco can with a hinged lid, and three crimped cans. No structural elements were discemable. The site covers an area of approximately $30,000 \mathrm{~m}^{2}$. Six of the artifacts were concentrated in a $1300-\mathrm{m}^{2}$ area. The site probably represents a sheepherder or cowboy camp dating to the early twentieth century. Little glass capable of becoming solarized was manufactured after 1917 (University of Utah and others 1984), and crown-top bottles patented in 1892 were universal for carbonated beverages by 1912 (University of Utah and others 1984). Hinge-lidded tobacco cans came into use in 1910 (University of Utah and others 1984).

(a) Ball Corporation, Muncie, Indiana.

(b) Kerr Glass Manufacturing Corporation, Sand Springs, Oklahoma. 


\subsubsection{Isolated Artifacts}

Three isolated artifacts, $\mathrm{HI}-88-001, \mathrm{HI}-88-002$, and $\mathrm{HI}-88-026$, were also recorded during the pedestrian survey. HI-88-001 is a 38 -caliber Winchester ${ }^{(a)}$ centerfire cartridge manufactured by the U.S. Repeating Arms Company. It is similar to the .38-40 Winchester dating from 19341937 (Berge 1980). Artifact HI-88-002 is a large (3.5-cm) unmodified cryptocrystalline flake, the only prehistoric, or at least aboriginally manufactured, artifact found during the survey. These two isolated artifacts were located $20 \mathrm{~m}$ apart. We do not know if the artifacts are associated with each other, or if their proximity is fortuitous. They were located about $300 \mathrm{~m}$ to the northwest of the projected trace of the White Bluffs Road and may be associated with its use. Artifacts HI-88-001 and HI-88-002 were collected and are presently being stored at the HCRL. Artifact HI-88-026 is a hole-in-top can located $760 \mathrm{~m}$ northwest of the White Bluffs Road, and was not collected.

\subsubsection{Other Cultural Remains}

Other cultural remains noted in the 200 West Area included concentrations of C-ration cans, towel scatters, and isolated milk cans. A concrete structure is located on the road that connected army camps of the 1950s and 1960s. An old dirt road can be traced along the edge of the 200 Area Plateau. The road is approximately $3 \mathrm{~m}$ wide and about $20 \mathrm{~cm}$ below grade. Mature shrubs are growing within the road bed. The road may predate the establishment of the Hanford Site.

(a) Winchester is a trade name of U.S. Repeating Arms Company, New Haven, Connecticut. 


\subsection{EVALUATION OF CULTURALRESOURCE SITES}

A property is eligible for nomination to the National Register of Historic Places if it meets the the following criteria (36 CFR Part 60.4):

The quality of significance in American history, architecture, archeology, engineering, and culture is present in districts, sites, buildings, structures, and objects that possess integrity of location, design, setting, materials, workmanship feeling, and association, and that (a) are associated with events that have made a significant contribution to the broad patterns of our history; or (b) that are associated with the lives of persons significant in our past; or (c) that embody the distinctive characteristics of a type, period, or method of construction, or that represent the work of a master, or that possess high artistic values, or that represent a significant distinguishable entity whose components may lack individual distinction; or (d) that have yielded or may be likely to yield information important in history or prehistory.

Cultural resource sites and features found during surveys of the 200 Areas were evaluated according to these criteria, with the following findings.

\subsection{EVALUATION OF HT-88-001 AND HT-88-009}

Sites similar to the can and bottle scatters of HT-88-001 and HT-88-009 are common throughout the West (Chatters 1980) and are not considered significant under any of the above criteria.

\subsection{EVALUATION OE THE WHTTE BLUFFS ROAD}

We believe that the White Bluffs Road meets criteria (a) and is representative of the theme of transportation as identified in the Hanford Cultural Resources Management Plan (Chatters 1989, Appendix E). The White Bluffs Road was an important transportation route during the mining, cattle ranching, and settlement eras in the Washington Territory. On the Hanford Site, the route was also evidently an Indian trail (Rice 1984) connecting an important water source, Rattlesnake Springs, with a favorite river crossing on the Columbia River at White Bluffs. Archaeological evidence supports these assertions.

As documented in Chatters (1989), the first use of the route by settlers was in 1853 by the Longmire party, the first wagon train to cross the Cascade Mountains to Puget Sound. After crossir g the Yakima River, the party proceeded to the northwest along the Cold Creek Valley. At 
Wells (Rattlesnake) Springs the wagon train reached a deep canyon that they were reluctant to cross. Thinking that they were lost, men were sent to scout for a better road. Indians that had been following the party marked two roads from the springs, one to the northeast and the other to the northwest. The Longmire Party mistakenly took the road to the northeast from Rattlesnake Springs to within sight of the White Bluffs. The next day they retraced their steps, traversed the canyon, and continued their journey on the correct road.

Shortly after the Longmire party's mistaken passage, the White Bluffs landing, a favorite river crossing and debarkation point of local Indians, became a central fording, supply and transshipment place for traders seeking to supply the British Columbia mines. By the spring of 1859 , steamboats were operating on the Columbia River from Portland to White Bluffs, which became one of several central points of transfer from river shipment to packtrains canrying supplies to miners (Splawn 1980). By 1860 there was apparently enough traffic on the road to support a ferry at White Bluffs. One such trader, Charles Splawn, along with Major John Thorp, traveled with a group of horses and pack saddles loaded with provisions from The Dalles to the Yakima Valley and crossed the Hanford Site along the White Bluffs Road to the White Bluffs ferry. In 1865, the Chief Factor of the Hudson's Bay Company ordered all of that organization's shipments from Portland to Fort Colville and the northern district sent via White Bluffs. For 2 years in the mid1860s, Andrew Splawn, along with some parmers, operated a pack train business between The Dalles and Rock 1sland. Their route forded the Yakima River near present-day Granger, crossed the Hanford Site along the White Bluffs Road to the White Bluffs ferry, and then followed Benjamin Snipes' cattle trail northward along the east bank of the Columbia.

In the late 1860s, the rising popularity of the Mullan Road, with its advantage of avoiding the sandy stretches north and east of White Bluffs, and the abandonment of the British Columbia mines caused a sharp decline in the ferry traffic at White Bluffs. The ownership and landing site of the White Bluffs ferry changed hands several times in the 1860 s and $1870 \mathrm{~s}$. The significance of the White Bluffs crossing can be seen when it is noted that in 1876, 20 soldiers were stationed there to protect travelers and ranchers. In July 1878, Wahluke Slope ranchers Lorenzo and Blanche Perkins crossed the Columbia at White Bluffs, traversed the Hanford Site via the White Bluffs Road, and were killed by Indians at Rattlesnake Springs.

The first known map of the White Bluffs Road in the Hanford vicinity was made in 1867 during the General Land Office Surveys (GLOs). On the south side of the Columbia River, the road on these early maps is described as a "Wagon Road" and as the "Road from Yakima to White Bluffs" (Rice 1984, Figure 5). The White Bluffs Road is mapped in more detail during later GLOs conducted in 1868,1880 , and 1881 . The road appeared to be the main northeast/southwest route 
across what is now the Hanford Site. No other roads are shown connecting to White Bluffs on the south side of the Columbia River. The road to the south of the Columbia River on the Hanford Site also appears on a map by Lieutenant Thomas W. Symons made in 1881 (Symons 1967).

The road appears on the 1916 edition of the USGS Coyote Rapids $15^{\prime}$ Quadrangle Map (Rice 1984, Figure 7). Again, the road appears to be the primary northeast/southwest route across what is now the Hanford Site. A section of the original road to the south of the Columbia River appears on the 1924 edition of the USGS Hanford 15' Quadrangle Map. The road is not mapped in the vicinity of east White Bluffs where north/south and east/west trending roads dominate. By 1951 the road across the Hanford Site had largely fallen into disuse. Only segments of the road, primarily those still in use, were mapped on the 1951 edition of the USGS Hanford 15' Quadrangle Map. To the north of the Columbia River, the road is marked as an unimproved road on the 1924 Hanford $15^{\prime}$ quadrangle. Less than 1 mile of the road is on the 1951 Hanford $15^{\prime}$ quadrangle.

Rice (1984) argued that because of lack of integrity, the segment of the White Bluffs Road east of U.S. Highway 240 did not appear to meet criteria for nomination to the National Register of Historic Places. The State Historic Preservation Officer concurred with this assessment in 1981. We believe that because more than $11.7 \mathrm{~km}$ of the road is extant on the east side of the highway and south of the river, the argument for lack of integrity is insupportable. In addition, Rice has suggested that there is the potential for graves along Indian trails. Because the White Bluffs Road was ar. Indian trail before becoming a road, there is the potential for graves along it.

Based on the evidence presented above, we conclude that the White Bluffs Road has played a significant part in transportation in the central Columbia Basin from prehistoric times until as late as the 1920s. The road is associated with many significant events, including the Longmire Party's traverse of the Cascade Mountains, the early cattle drives, and the killing of settlers at Rattlesnake Springs during the Indian wars of the nineteenth century. Therefore, it is our recommendation that the White Bluffs Road be nominated to the National Register of Historic Places under criterion (a), which addresses contribution to the broad patterns of history. We will seek a determination of eligibility from the State Historic Preservation Officer. 
'

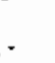

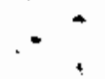

: 


\subsection{CONCLUSIONS AND RECOMMENDATIONS}

The archaeological surveys conducted in the 200 Areas of the Hanford Site demonstrated that archaeological resources are scarce. The only potentially significant cultural resource found in the area was the White Bluffs Road that ran between Rattlesnake Springs and the White Bluffs along the Columbia River. This road served at various times as an Indian trail, settlers' trail, and a freight road.

As a result of these findings, we have created two archaeological sensitivity zones within the fences surrounding the 200 East and 200 West Areas, a no-sensitivity zone and a highsensibvity zone. The high-sensitivity zone is a band within $100 \mathrm{~m}$ of either side of the White Bluffs Road in the northwest corner of the 200 West Area. The no-sensitivity area is all other portions of both areas.

Cultural resource reviews will continue to be required for any project proposed for the high-sensitivity zone, whereas reviews will not be required for the no-sensitivity zone. The exceptions to this finding are projects entailing renovation or demolition of standing structures and buildirgs, which are nor covered by this report and will continue to require cultural resource review's. 


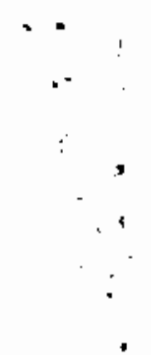

. 


\subsection{REEERENCES}

Berge, D. L. 1980. Simpson Springs Station-Historical Archaeology in Western Utah. 1974 1975. Cultural Resource Series No. 6, Utah State Office, Bureau of Land Management, Provo, Utah.

Chatters, J. C. 1980. Cultural Resources of the Columbia Basin Project: An Inventory of Selected Parcels. Office of Public Archaeology, Reconnaissance Report No. 32. University of Washington, Seattle, Washington.

Chatters, J. C. 1989. Hanford Cultural Resources Management Plan. PNL-6942, Pacific Northwest Laboratory, Richland, Washington.

Daubenmire, R. 1970. Steppe Vegetation of Washington. Technical Bulletin 62, Experimental Station, Washington State Üniversity, Pullman, Washington.

ERTEC. 1982. A Cultural Resources Overview and Scenic and Natural Resources Assessment for the Skagit-Hanford Nuclear Power Rroject. ERTEC Northwest, Seattle, Washington.

Rice, D. G. 1980. Overview of Cultural Resources on the Hanford Reservation in South Central Washington State. RL-E-80-0043, prepared for the U.S. Department of Energy, Richland Operations, Richland, Washington.

Rice, D. G. 1984. Archaeological Inventory of the Basalt Waste Isolation Project. Hanford Reservation. Washington. SD-BWI-TA-006, Rockwell Hanford Operations, Richland, Washington.

Smith, W. C., M. L. Uebelacker, T. E. Eckert, and L. J. Nickel. 1977. An ArchaeologicalHistorical Survey of the Proposed Transmission Power Line Corridor from Ashe Substation Washington to Pebble Springs Substation. Oregon. Archaeological Research Center Project Report 42, Washington State University, Pullman, Washington.

Splawn, A. J. 1980. Kamiakin - Last Hero of the Yakimas. Caxton Printer, Caldwell, Idaho. (Reprint of 1917 ed.)

Symons, T. W. 1967. The Symons Report on the Upper Columbia and the Great Plain of the Columbia. Ye Galleon Press, Fairfield, Washington. (Reprint of 1882 Senate Document 186, 47th Congress)

University of Utah, the Bureau of Land Management, and the U.S. Forest Service. 1984. Intermountain Antiquities Computer System-Users Guide. Instruction and Computer Codes for Use with the IMACS Site Form. Salt Lake City, Utah. 
$\therefore$

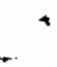

$r$ 


\section{DISTRIBUTION}

No. of

Copies

Offsite

2 DOE/Office of Scientific and Technical Information

Onsite

24 DOE-RL

K. V. Clarke (20)

N. M. Highland

M. B. Hitt

K. J. Wheeless

DOE Legal Library
23 Pacific Northwest Laboratory

N. A. Cadoret

J. C. Chatters

R. M. Ecker (5)

J. W. Falco

R. H. Gray

J. M. Hales

M. S. Hanson

P. C. Hays

W. T. Pennell

J. T. A. Roberts

L. E. Rogers

R. L. Skaggs

W. L. Templeton

Publishing Coordination

Technical Report Files (5)

4 Westinghouse Hanford Company
K. W. Leliefeld
D. L. Mills
E. T. Trost
O. Tuttle

Distr.1 

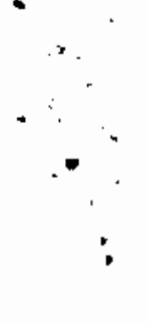